\title{
An Inotropic Action Caused by Muscarinic Receptor Subtype 3 in Canine Cardiac Purkinje Fibers
}

\author{
Katsuharu Tsuchida, ${ }^{1}$ Yumiko Mizukawa, ${ }^{2}$ Tetsuro Urushidani, ${ }^{2}$ \\ Shigehiro Tachibana, ${ }^{3}$ and Yukiko Naito ${ }^{3}$ \\ ${ }^{1}$ Department of Rational Medicinal Science, Faculty of Pharmaceutical Sciences, Doshisha Women's College, Kyoto, \\ Kyotanabe-shi 610-0395, Japan \\ ${ }^{2}$ Department of Pathological Physiology, Faculty of Pharmaceutical Sciences, Doshisha Women's College, Kyoto, \\ Kyotanabe-shi 610-0395, Japan \\ ${ }^{3}$ Department of Pharmacology, Hatano Research Institute, Food and Drug Safety Center, Kanagawa, \\ Hadano-shi 257-8523, Japan \\ Correspondence should be addressed to Katsuharu Tsuchida; ktsuchid@dwc.doshisha.ac.jp
}

Received 5 July 2013; Accepted 28 August 2013

Academic Editors: K. Cimanga, R. Fantozzi, M. C. Olianas, and J. D. Salamone

Copyright ( 2013 Katsuharu Tsuchida et al. This is an open access article distributed under the Creative Commons Attribution License, which permits unrestricted use, distribution, and reproduction in any medium, provided the original work is properly cited.

Objective. The objective of this study was to investigate the inotropic mechanisms and the related muscarinic receptor subtype of acetylcholine (ACh) in canine cardiac Purkinje fibers. Materials and Methods. Isolated Purkinje fiber bundles were used for the measurement of contraction. The receptor subtype was determined using PCR and real-time PCR methods. Results. ACh evoked a biphasic response with a transient negative inotropic effect followed by a positive inotropic effect in a concentration-dependent manner. The biphasic inotropic actions of ACh were inhibited by the pretreatment with atropine. Caffeine inhibited the positive inotropic effect of ACh. ACh increased inositol-1,4,5-trisphosphate content in the Purkinje fibers, which was abolished by atropine. Muscarinic subtypes $2\left(\mathrm{M}_{2}\right)$ and $3\left(\mathrm{M}_{3}\right)$ mRNAs were detected in the canine Purkinje fibers albeit the amount of $\mathrm{M}_{3}$ mRNA was smaller than $\mathrm{M}_{2}$ mRNA. $\mathrm{M}_{1}$ mRNA was not detected. Conclusion. These results suggest that the positive inotropic action of ACh may be mediated by the activation of $\mathrm{IP}_{3}$ receptors through the stimulation of $\mathrm{M}_{3}$ receptors in the canine cardiac Purkinje fibers.

\section{Introduction}

Five muscarinic acetylcholine receptors (mAChRs) have been identified and studied extensively and functionally elucidated [1]. Functions of these ACh receptor subtypes have been determined in the heart as well as other tissues or organs [2]. A lot of experiments have showed that $\mathrm{M}_{2}$ of $\mathrm{mAChRs}$ plays an important role in exerting the negative chronotropic action in the sinoatrial node or the negative inotropic action in the atria by activating potassium channels and/or inhibiting adenylate cyclase via $\mathrm{G}_{\mathrm{i} / \mathrm{o}}$ protein. It has been demonstrated that the stimulation of ACh exerts the biphasic inotropic actions in the atria and ventricles of various species [2]. The negative inotropy is attributable to the activation of $G_{i / o}$ in atrial muscles, whereas the mechanisms of AChinduced positive inotropic action are assumed to be due to the activation of $G_{\mathrm{q}}$ protein in the ventricles and atria
[2-4]. However, in cardiac Purkinje fibers, the existence or function of muscarinic receptor subtypes still remains a little bit uncertain compared with atria and ventricles. There have been several mechanical tensions, electrophysiological, or biochemical studies regarding the effects of $\mathrm{ACh}$ on cardiac Purkinje fibers [5-8]. Curiously enough in the cardiac Purkinje fibers, there has however been no obvious study drawing the conclusion that the stimulation of muscarinic 3 receptors causes the ACh-evoked positive inotropy. In this study, we examined the underlying mechanisms by which ACh evokes the positive inotropic response in the canine Purkinje fibers.

\section{Materials and Methods}

2.1. Preparation for the Bundles of Fibers and Experimental Protocols of Contractile Force Measurements. Twelve mongrel 
dogs (13-18 kg, both sexes), purchased from Kitayama Labes (Nagano, Japan), were used. The animals were intravenously anesthetized with sodium pentobarbital $(30 \mathrm{mg} / \mathrm{kg})$. Their hearts were quickly removed by lateral thoracotomy. Purkinje fibers were excised from the ventricles in cold oxygenated Tyrode's solution. As already reported in our previous papers [9], fibers less than $0.8 \mathrm{~mm}$ in a diameter and $6-10 \mathrm{~mm}$ in length were immersed in a tissue bath $(20 \mathrm{~mL}$ in volume $)$ with the following composition (mM): $\mathrm{NaCl} 140.3, \mathrm{KCl} 2.7, \mathrm{CaCl}_{2}$ 1.8, $\mathrm{MgCl}_{2} 1.1, \mathrm{NaH}_{2} \mathrm{PO}_{4}$ 0.4, $\mathrm{NaHCO}_{3} 11.9$, and glucose 5.6. The solution was adjusted to $\mathrm{pH} 7.4$ by $\mathrm{NaOH}$ and was gassed with $95 \% \mathrm{O}_{2}$ and $5 \% \mathrm{CO}_{2}$; the temperature of the bath was maintained at $36-37^{\circ} \mathrm{C}$ during the tension experiment. The bundles of fibers were stimulated at a rate of $1 \mathrm{~Hz}$, with rectangular pulses of 2-4 ms duration and at a voltage of twice the threshold voltage through a bipolar platinum electrode attached to the preparation and connected to an electric stimulator (SEN-7103, Nihon Kohden, Tokyo, Japan). Prior to beginning the study regarding the developed tension, a 60-90 min equilibration was allowed. During equilibration, Tyrode's solution was replaced with fresh solution every 20 $30 \mathrm{~min}$. Developed tension was measured with an isometric force-displacement transducer (SB-1T, Nihon Kohden) with the application of a $0.5 \mathrm{~g}$ preload.

\section{2. $I_{3}$ Production in Canine Cardiac Purkinje Fibers Stim-} ulated with Acetylcholine. Five male beagle dogs weighing 11-14 kg (Covance Research Products, Kalamazoo, MI, USA) were used. According to the above mentioned method, Purkinje fibers were excised from the ventricles and immersed in a mini-Magnus tube $(2 \mathrm{~mL}$ in volume, Medical Kishimoto, Kyoto, Japan) filled with Tyrode's solution. This solution was gassed with $95 \% \mathrm{O}_{2} / 5 \% \mathrm{CO}_{2}$, and its temperature was maintained at $36^{\circ} \mathrm{C}(\mathrm{pH}$ 7.4). After equilibration, Purkinje fibers were incubated with ACh $10^{-4} \mathrm{M}$ for $90 \mathrm{sec}$. To examine the inhibitory effect of muscarinic receptors on $\mathrm{IP}_{3}$ production, pretreatment with atropine $10^{-5} \mathrm{M}$ for $3 \mathrm{~min}$ was performed before the incubation with ACh. The fibers incubated in Tyrode's solution without these reagents were regarded as control. These reagents $(20 \mu \mathrm{L})$ were added directly to a $2 \mathrm{~mL}$ mini-Magnus containing Tyrode's solution. After the incubation, Purkinje fibers were frozen immediately in liquid nitrogen and stored at $-80^{\circ} \mathrm{C}$ until measurements of $\mathrm{IP}_{3}$. The methods of measurements of $\mathrm{IP}_{3}$ levels were as follows. Frozen Purkinje fibers were homogenized in ice-cold 10 $\mathrm{v} / \mathrm{v} \%$ perchloric acid with Ultra Sonic Homogenizer (UH50, SMT, Tokyo, Japan). After centrifugation at 2,000 $\times$ g for $10 \mathrm{~min}$ at $4^{\circ} \mathrm{C}$, the supernatants obtained were neutralized to $\mathrm{pH} 7.5$ with ice-cold $1.5 \mathrm{M}$ potassium hydroxide solution containing $60 \mathrm{mM}$ HEPES and centrifuged at 2,000 $\times \mathrm{g}$ for $10 \mathrm{~min}$ at $4^{\circ} \mathrm{C}$. The supernatants were used for a subsequent measurement of $\mathrm{IP}_{3}$ concentration as samples. $\mathrm{IP}_{3}$ concentration was determined by Inositol-1,4,5-trisphosphate $\left[{ }^{3} \mathrm{H}\right]$ Radioreceptor Assay Kit (PerkinElmer Life \& Analytical Sciences, Waltham, MA, USA) according to the instruction manual. Assay was carried out in duplicate. Samples and radiolabeled $\mathrm{IP}_{3}$ tracer $\left({ }^{3} \mathrm{H}\right)$ were mixed and incubated for $1 \mathrm{~h}$ on ice. After centrifugation at $2,500 \times \mathrm{g}$ for $15 \mathrm{~min}$ at $4^{\circ} \mathrm{C}$, the pellets were collected and dissolved in $0.15 \mathrm{M}$ sodium hydroxide solution. Pellets dissolved were kept statically at room temperature for $10 \mathrm{~min}$. They were poured into the glass vials and mixed with Atomlight scintillation cocktail (PerkinElmer Life \& Analytical Sciences). Radioactivity $\left({ }^{3} \mathrm{H}\right)$ was determined by liquid scintillation counter (LS-3801, Beckman Coulter, Fullerton, CA, USA). In addition, protein concentration in the samples was determined according to the Bradford method (Bio-Rad Laboratories, Hercules, CA, USA) using bovine serum albumin (Sigma-Aldrich, St. Louis, MO, USA) for standard curve. Absorbance was detected by the microplate reader (Varioskan Flash, Thermo Fisher Scientific, Waltham, MA, USA).

\subsection{Reverse Transcription-Polymerase Chain Reaction (RT-} $P C R$ ). Five other male beagle dogs (Covance Research Products, Kalamazoo, MI, USA) were used to collect Purkinje fibers. Dissected Purkinje fibers $(60-130 \mathrm{mg})$ from three dogs were soaked in the tubes containing $1 \mathrm{~mL}$ of RNAlater (Life Technologies, Carlsbad, CA, USA). Dissected atrial muscles and salivary glands $(60-185 \mathrm{mg})$ were also collected likewise as positive controls. The samples were kept at $4^{\circ} \mathrm{C}$ for overnight and then stored at $-80^{\circ} \mathrm{C}$ until use. Total RNA was isolated using RNeasy mini kit (Qiagen, Hilden, Germany). The samples were homogenized in $1.0-1.4 \mathrm{~mL}$ of Buffer RLT (a component of the kit) with zirconium beads using a Mixer Mill MM301 (Retsch, Haan, Germany). An aliquot of the tissue homogenate ( 350 or $700 \mu \mathrm{L}$ ) was mixed with 2 volumes of TRIzol LS reagent (Life Technologies, Carlsbad, CA, USA) and an equivalent volume of chloroform. The mixture was centrifuged at $18,000 \times \mathrm{g}$ for $15 \mathrm{~min}$ at $4^{\circ} \mathrm{C}$, and the resultant aqueous layer was transferred to a new tube. An equivalent volume of $70 \%$ ethanol was added to the solution and mixed by pipetting. The mixture was transferred to an RNeasy mini column. The following procedure was performed according to the manufacturer's instructions. In order to remove genomic DNA, on-column digestion by DNase I was performed during the procedure. The concentration of the total RNA was determined by absorbance at $260 \mathrm{~nm}$. Purity and integrity of the total RNA were confirmed by absorbance ratio at 260 and $280 \mathrm{~nm}$ and agarose gel electrophoresis. One microgram of total RNA from each sample was reverse-transcribed using QuantiTect Reverse Transcription kit (Qiagen, Hilden, Germany) according to the manufacturer's instructions. A control sample was prepared in parallel with each cDNA sample by replacing reverse transcriptase with RNase-free water. One-fortieth of each reverse transcription (RT) product was used for the following polymerase chain reaction (PCR), which was conducted using Taq DNA polymerase (Takara Bio, Otsu, Japan) and primers for canine $M_{1}, M_{2}$, or $M_{3}$ receptors of mAChRs. The primers were purchased from Qiagen (Cf_CHRM1_1_SG, Cf_CHRM2_2_SG, or Cf_CHRM3_1_SG QuantiTect Primer Assay). Cycling conditions were as follows: initial denaturation $\left(4^{\circ} \mathrm{C}\right.$ for $1 \mathrm{~min}, 94^{\circ} \mathrm{C}$ for $1 \mathrm{~min}$ ), followed by 28 cycles of denaturation $\left(96^{\circ} \mathrm{C}\right.$ for $\left.20 \mathrm{sec}\right)$, annealing $\left(60^{\circ} \mathrm{C}\right.$ for $\left.30 \mathrm{sec}\right)$, and extension $\left(72^{\circ} \mathrm{C}\right.$ for $\left.30 \mathrm{sec}\right)$. An additional extension step $\left(72^{\circ} \mathrm{C}\right.$ for $7 \mathrm{~min}$ ) was performed. The RT-PCR products were 
TABle 1: Amount of gene expression of mAChR subtypes in Purkinje fibers.

\begin{tabular}{lccr}
\hline & $\mathrm{M}_{1}$ & $\mathrm{M}_{2}$ & $\mathrm{M}_{3}$ \\
\hline Purkinje fiber & $<6.0 \times 10^{-4}$ & $1.6 \times 10^{-1} \pm 8.5 \times 10^{-3}$ & $1.5 \times 10^{-3} \pm 1.2 \times 10^{-4}$ \\
Salivary gland & $5.1 \times 10^{-2} \pm 2.3 \times 10^{-2}$ & $3.9 \times 10^{-3} \pm 1.6 \times 10^{-3}$ & $1.5 \times 10^{-2} \pm 6.3 \times 10^{-3}$ \\
Atrial muscle & $<4.4 \times 10^{-4}$ & $2.1 \times 10^{-1} \pm 1.1 \times 10^{-2}$ & $8.6 \times 10^{-4} \pm 4.1 \times 10^{-4}$ \\
\hline
\end{tabular}

separated and visualized in ethidium bromide containing 3\% agarose gel by electrophoresis.

One-hundredth of each RT product was used for quantitative real-time PCR. Real-time PCR was performed with Rotor-Gene Q (Qiagen, Hilden, Germany) using SYBR premix Ex Taq II (Takara Bio, Otsu, Japan) with the following thermal profile: initial denaturation step $\left(95^{\circ} \mathrm{C}\right.$ for $3 \mathrm{~min}), 40$ cycles of denaturation $\left(95^{\circ} \mathrm{C}\right.$ for $\left.10 \mathrm{sec}\right)$, annealing $\left(60^{\circ} \mathrm{C}\right.$ for $\left.10 \mathrm{sec}\right)$, extension step $\left(72^{\circ} \mathrm{C}\right.$ for $\left.30 \mathrm{sec}\right)$, and final step for melting curve generation $\left(65-95^{\circ} \mathrm{C}, 1^{\circ} \mathrm{C}\right.$ per sec). Primers were from Qiagen (Cf_RPLP0_2_SG QuantiTect Primer Assay, or primers for mAChRs used also for semiquantitative RT-PCR). The cycle threshold (Ct) values were measured. The amount of each gene was calculated using standard curve obtained from serially diluted PCR amplicon which was cloned into pCRII-TOPO vector (Life Technologies, Carlsbad, CA, USA) and linearized by digestion with XhoI. Relative expression levels of $\mathrm{mAChR}$ subtypes were calculated as ratios of target amounts to the amount of a housekeeping gene, "ribosomal protein, large P0 (RPLP0)".

All the animals used in the present experiments were kept in air-conditioned room and supplied with solid foods (DSA, Oriental Yeast, Tokyo, Japan) and water freely. Animal experiments were conducted in compliance with "Guideline for Animal Experiment in Hatano Research Institute, Food and Drug Safety Center, Taisho Pharmaceuticals, or Doshisha Women's College."

2.4. Chemicals. The following drugs were used: acetylcholine chloride (Sigma-Aldrich, St. Louis, MO, USA); atropine sulfate monohydrate (Wako Pure Chemical Industries, Osaka, Japan); l-isoproterenol hydrochloride (Nikken Chemicals, Tokyo, Japan); caffeine sodium benzoate (Sigma-Aldrich). The agents were dissolved in distilled water as stock solution. On the day of experiment, fresh solution was made from stock by adding to external recording solution.

2.5. Statistical Analysis. Statistical significance tests were performed by repeated measures of one-way ANOVA, paired Student's $t$-test, or Wilcoxon's $t$-test. The values were expressed as the mean \pm SEM. $P$ value of less than 0.05 was considered statistically significant.

\section{Results}

3.1. Characteristic Changes of Contractile Force Evoked by Acetylcholine. Canine Purkinje fiber bundles were driven at $1 \mathrm{~Hz}$. Figure 1(a) shows that cumulatively applied acetylcholine (ACh) at concentrations of $10^{-6}, 10^{-5}$, and $10^{-4} \mathrm{M}$ decreased the contractile force transiently and then increased the contractile force in a concentration-dependent manner. In the experiment examining the effects of cumulatively applied ACh, the first application of ACh at $10^{-6} \mathrm{M}$ decreased contractile force by $3.4 \pm 0.5 \%(P<0.01)$ and increased the force by $18 \pm 3.3 \%(P<0.01)(n=5)$. In the experiment for a single application of $\mathrm{ACh} 10^{-4} \mathrm{M}$, the transient decrease in the contractile force was more evident, which was replaced by the increase in the contractile force (Figure 1(b)). These biphasic responses were abolished by the pretreatment with nonspecific antagonist, atropine $10^{-6} \mathrm{M}$ completely. Figure 2(a) shows concentration-response relationships of the positive inotropic actions caused by ACh. Figure 2(b) shows pooled data of negative and positive inotropic effects provoked by single application of ACh $10^{-4} \mathrm{M}$. As shown in Figure 3(a), caffeine at 1-3 mM affected $\mathrm{ACh}$ - and Isoproterenol- (Iso-) induced changes of contractile force. The typical tracings of Figure 3(a) show that the Iso-induced increase in contractile force were affected more readily by the pretreatment with caffeine than ACh-induced one. The ACh $\left(10^{-4} \mathrm{M}\right)$-evoked positive inotropy was attenuated by caffeine $1 \mathrm{mM}$ but still remained a little (Figure 3(b)). On the other hand, the Iso $\left(10^{-6} \mathrm{M}\right)$-evoked positive inotropy was inhibited completely by $100 \%$ by $1 \mathrm{mM}$ caffeine. Caffeine $3 \mathrm{mM}$ abolished AChevoked positive inotropy completely by $100 \%$ (Figure 3(b)).

\section{2. $\mathrm{IP}_{3}$ Levels in Canine Cardiac Purkinje Fiber Bundle} Preparation. Results of $\mathrm{IP}_{3}$ levels in the samples are represented in Figure 4. $\mathrm{IP}_{3}$ levels in the Purkinje fibers incubated with ACh $10^{-4} \mathrm{M}$ were significantly increased compared with the control. The ACh-evoked increase in $\mathrm{IP}_{3}$ levels was inhibited significantly to the control level by pretreatment with atropine $10^{-5} \mathrm{M}$.

3.3. RT-PCR Products from the Canine Cardiac Purkinje Fibers, Atrial Muscle, and Salivary Gland. Expression of mAChR subtypes in Purkinje fibers was examined by RTPCR (Figure 5). The RT-PCR product corresponding to $\mathrm{M}_{2}$ receptors was clearly detected in Purkinje fibers. The product corresponding to $\mathrm{M}_{3}$ receptors was also detected, but the amplitude of the expression was smaller than that of $\mathrm{M}_{2}$ receptors. Collected data showed about one fiftieth of the density of $\mathrm{M}_{3}$ receptor mRNA to that of $\mathrm{M}_{2}$ receptor mRNA (Table 1 ). $M_{1}$ receptor expression was rarely detected. The products for all the three subtypes were clearly detected in positive control samples (salivary glands for $M_{1}$ and $M_{3}$ receptors and atrial muscles for $\mathrm{M}_{2}$ receptors). Genomic contamination was negligible because no PCR product was detected in any RT-free sample under the cycling conditions employed here. 

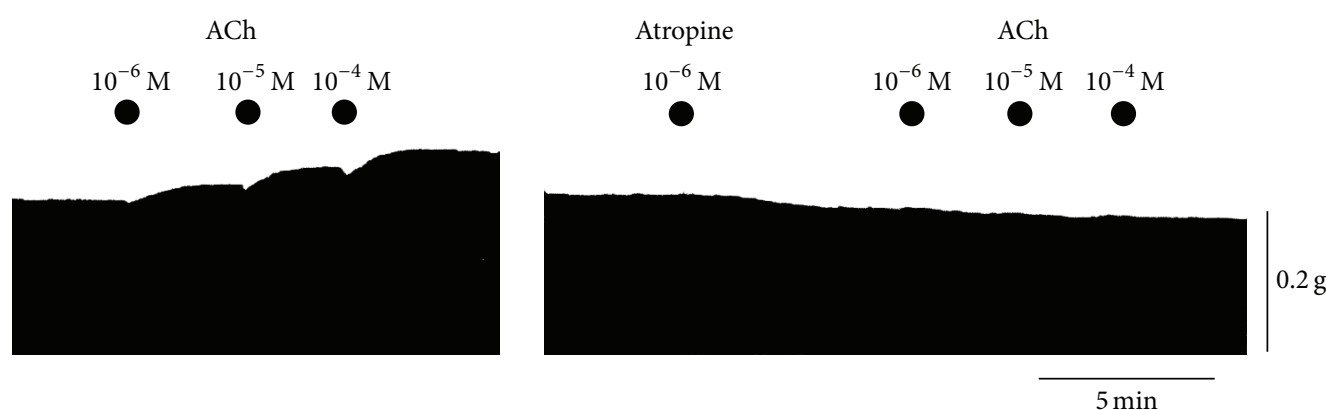

(a)

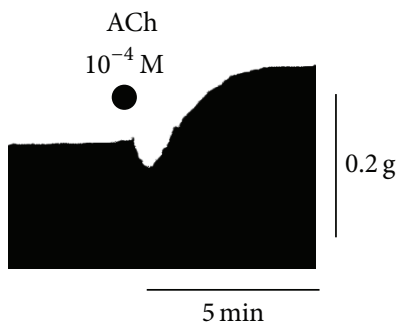

(b)

Figure 1: Inotropic effects of ACh on canine cardiac Purkinje fibers and effects of pretreatment with atropine on the ACh-evoked responses. (a) Typical tracings of effects of cumulatively applied ACh and atropine pretreatment on ACh-evoked inotropy. (b) Typical tracings of single application of $\mathrm{ACh} 10^{-4} \mathrm{M}$ on the inotropy.

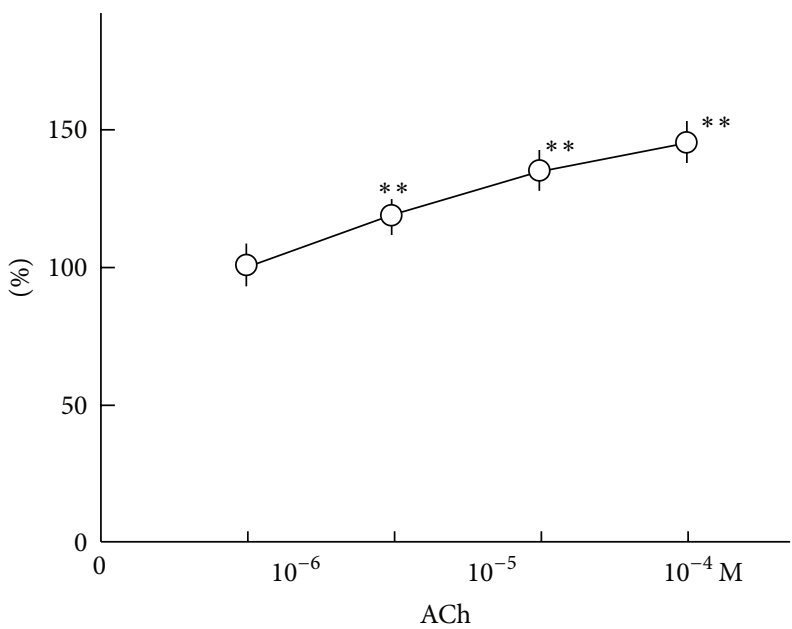

(a)

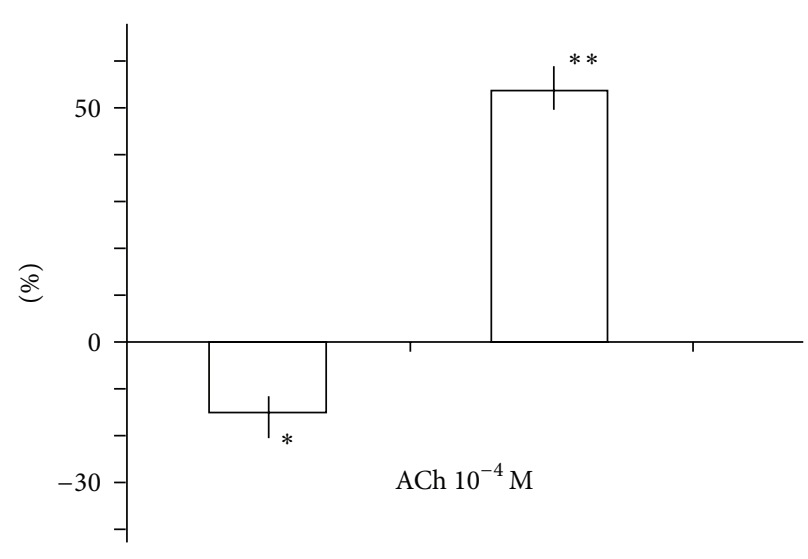

(b)

FIGURE 2: Effects of ACh on contractile force in canine cardiac Purkinje fibers. (a) Concentration-response relationships of the ACh-evoked positive inotropic effects in canine cardiac Purkinje fibers. Fibers were exposed in $1.8 \mathrm{mM}$ Tyrode's solutions. Circles with vertical bars indicate the mean \pm SEM $(n=5)$. (b) Biphasic responses of single application of ACh $10^{-4} \mathrm{M}$. Columns with vertical bars indicate the mean \pm SEM $(n=4)$. Each point shows the rates of changes versus control, and statistical significance was performed using raw data. $* *<0.01, *<0.05$ significantly different from control values ((a) one-way repeated measures ANOVA; (b) paired Student's $t$-test).

\section{Discussion}

$\mathrm{M}_{2}$ receptors are widely known to play important roles in the regulation of heart function. In addition, recent studies have demonstrated the existence of $M_{1}$ and $M_{3}$ receptors in the atria and ventricles, although the predominant subtype is $M_{2}$ in the atria $[2,10] . M_{3}$ receptors were found in the heart of several species including humans, dogs, cats, guinea-pigs, rats, mice, and chicks. On the other hand, evidence against the presence of the $M_{3}$ receptors has also obtained from some of these species [2]. $\mathrm{M}_{2}$ receptor stimulation induces negative inotropic and chronotropic actions by activating the $G$ protein-coupled potassium channel and/or inhibiting adenylate cyclase $[2,11]$. In contrast, the stimulation of $\mathrm{M}_{3}$ 


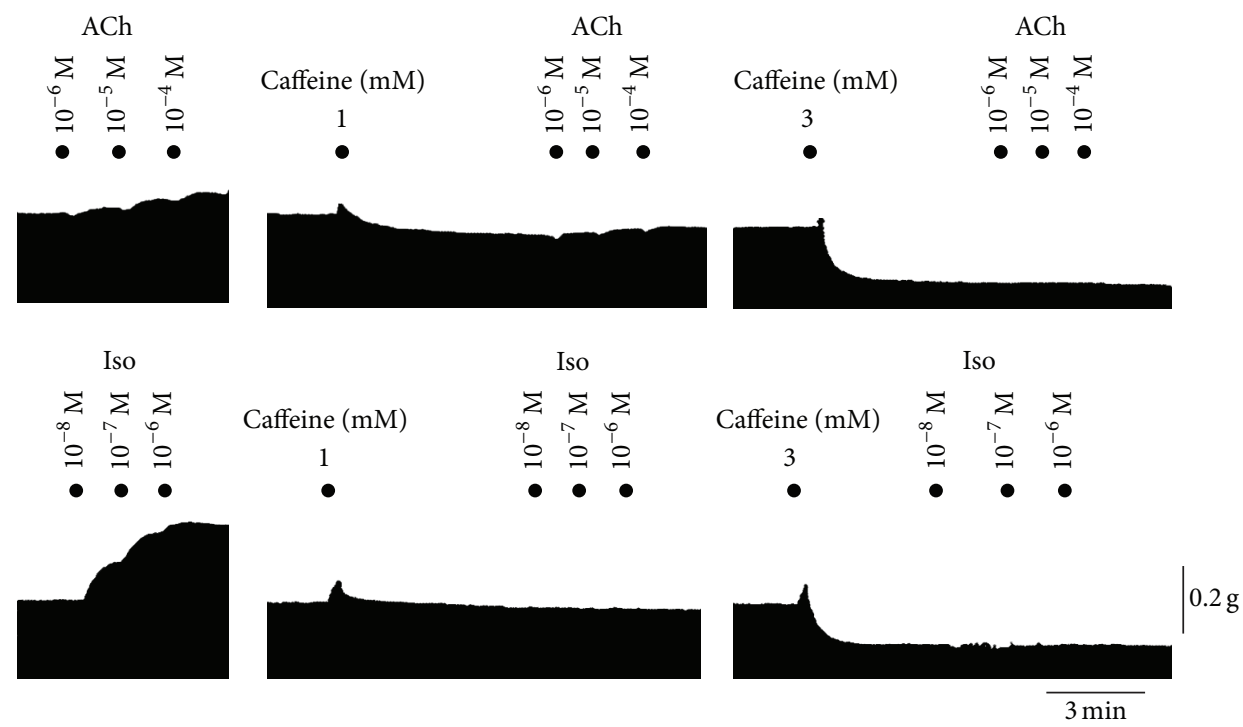

(a)

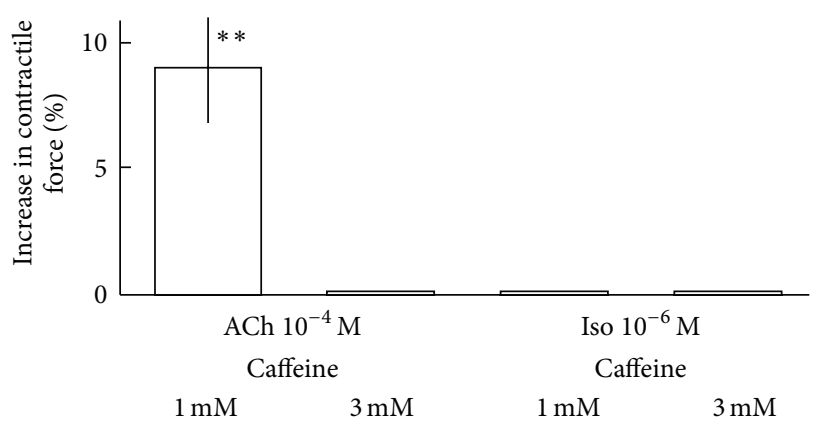

(b)

FIGURE 3: Influences of caffeine pretreatment on ACh- or Iso-evoked positive inotropy in canine cardiac Purkinje fibers. (a) Typical tracings of the inhibitory effects of caffeine on ACh-evoked inotropy or Iso-evoked inotropy. (b) Pooled data of effects of pretreated caffeine on ACh or Iso-evoked positive inotropy. Columns show the percent increase in contractile force in the presence of caffeine 1 or $3 \mathrm{mM}$, and vertical bar indicates SEM $(n=4) . * *<0.01$ significantly different from control values before ACh or Iso application (paired Student's $t$-test or Wilcoxon's $t$-test).

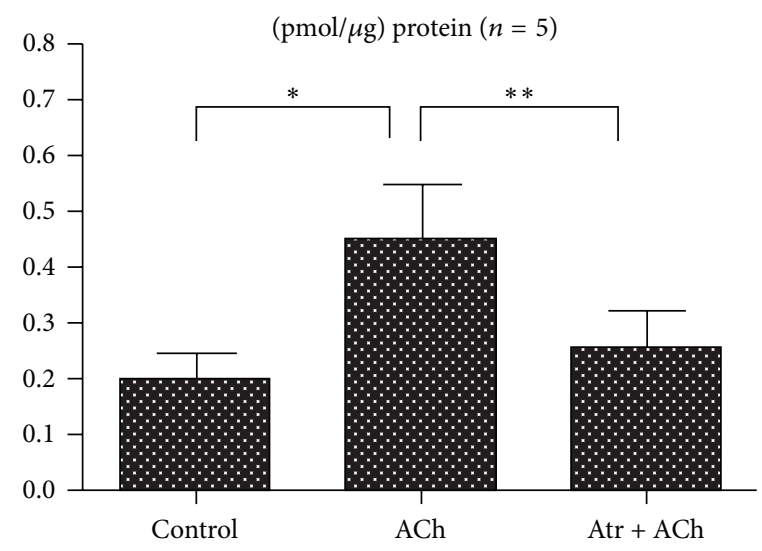

FIgURE 4: $\mathrm{IP}_{3}$ levels in canine cardiac Purkinje fibers treated by ACh or ACh and atropine (Atr). Columns with vertical bars indicate the mean $\pm \operatorname{SEM}(n=5) . *<0.05, * *<0.01$ significantly different from each other (paired Student's $t$-test). 


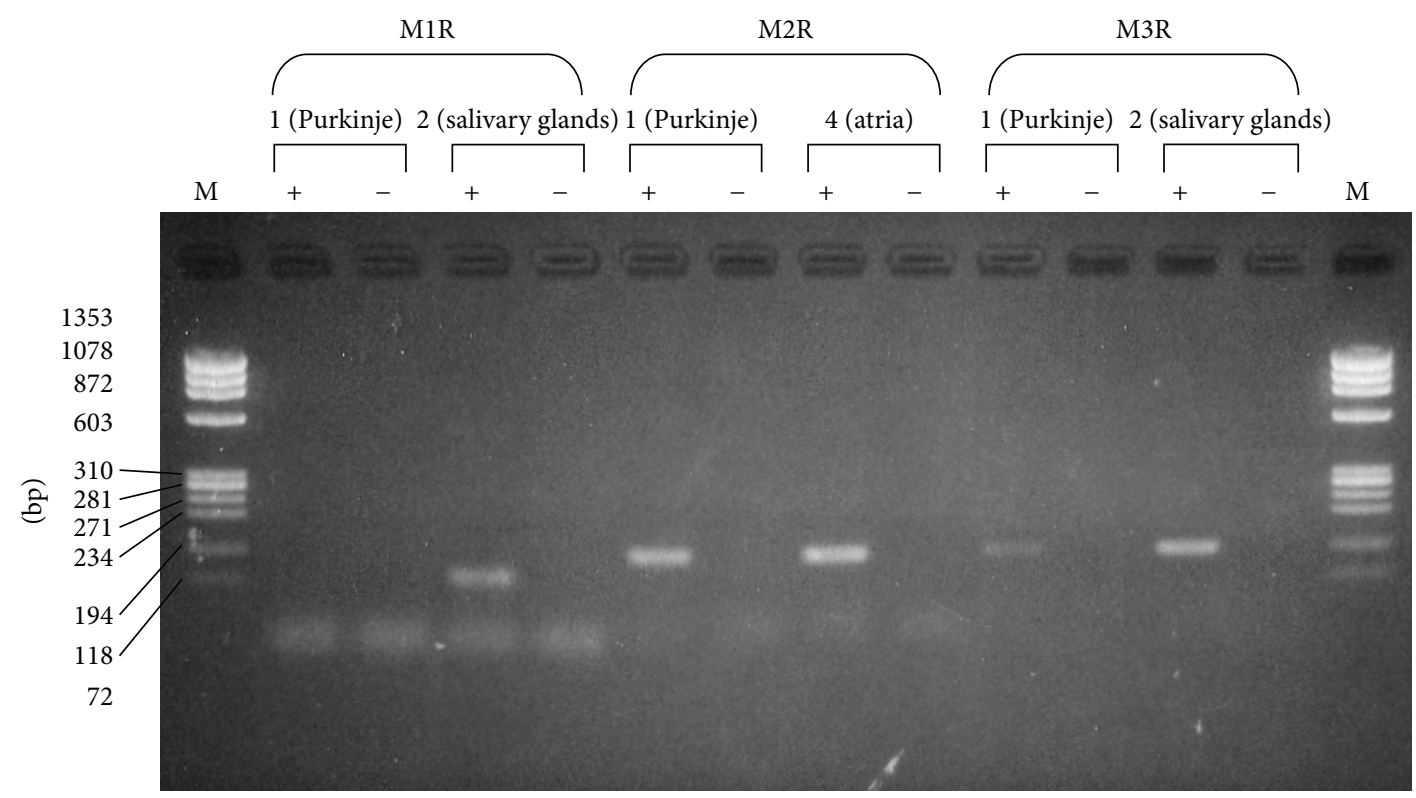

FIGURE 5: Gene expression of mAChR subtypes in Purkinje fibers. RT-PCR products for $\mathrm{M}_{1}$ (70 bp), $\mathrm{M}_{2}$ (106 bp), and $\mathrm{M}_{3}$ (109 bp) subtypes were analyzed by agarose gel electrophoresis. RT+ represents reverse-transcribed samples, and RT- represents corresponding reverse transcriptase-free controls. Salivary gland was used as positive control.

receptors was known to increase $\mathrm{IP}_{3}$ levels in the atria and ventricles $[2,3,12]$. There have been several electrophysiological or mechanical tension experiments showing the existence of muscarinic receptors by using pharmacological agents mainly such as $M_{1}$ and $M_{2}$ receptor antagonists in the cardiac Purkinje fibers. As a matter of fact, none of these studies came to the conclusion that the direct stimulation of muscarinic 3 receptor elicited the positive inotropy in cardiac Purkinje fibers. Curiously enough, muscarinic 3 receptor has not been paid much attention until now in the cardiac Purkinje fibers. $M_{1}$ was related to positive inotropy or the increase in automaticity of the fibers, and $\mathrm{M}_{2}$ was related to negative inotropy or the decrease in the automaticity [5$8,13]$.

In the studies using atria and ventricles, several studies demonstrated that $M_{3}$ receptor stimulation increased prostaglandin $(\mathrm{PG})$ production in the endocardial endothelium which caused positive inotropy in the mouse atria [1417]. In contrast, Ateş and Kaygisiz reported that the positive inotropy was not dependent on PG production in rat hearts [18]. However, it is not evident whether PG is related to the positive inotropy or not in canine Purkinje fibers since we have not examined PG production in the present study.

The treatment with caffeine markedly affected the inotropy evoked by ACh. Caffeine was demonstrated to affect the positive inotropy by depleting the caffeine-sensitive $\mathrm{Ca}$ storage sites in the ventricular cells or tissues $[19,20]$; thus, such actions were assumed to be exerted by caffeine in the Purkinje fibers as well. In the present study, the AChevoked positive inotropy was attenuated or abolished by the pretreatment with caffeine. The Iso-evoked positive inotropy was more readily affected by caffeine treatment. $1 \mathrm{mM}$ caffeine was enough to abolish the positive inotropy caused by Iso at
$10^{-6} \mathrm{M}$ completely. Whereas ACh-evoked positive inotropy remained to a little extent after the treatment caffeine $1 \mathrm{mM}$, and $3 \mathrm{mM}$ was needed to abolish the ACh-evoked positive inotropy completely. If ACh-evoked positive inotropy might be induced at least partly by $\mathrm{IP}_{3} \mathrm{R}$-sensitive Ca release from $\mathrm{Ca}$ storage sites, and these sites are less sensitive to caffeine compared with ryanodine-sensitive $\mathrm{Ca}$ storage sites, then the lesser extent of the inhibition of ACh-evoked positive inotropy by the treatment with caffeine would be plausible [21]. It is known that open probability of the ryanodine receptors (RyRs), mainly responsible for contraction, is increased resulting from a local increase of cytoplasmic $\mathrm{Ca}^{2+}$ concentration. It might be possibly occurred that the increase in local $\left[\mathrm{Ca}^{2+}\right]_{\mathrm{i}}$ near vicinity of RyRs is subsequently induced by $\mathrm{IP}_{3} \mathrm{R}$-induced $\mathrm{Ca}^{2+}$ release in canine cardiac Purkinje cells as indicated by Stuyvers et al. [21, 22]. It was demonstrated that millimolar concentrations of caffeine blocks $\mathrm{IP}_{3}$ Rs [23], thus caffeine $3 \mathrm{mM}$ eventually abolished ACh-evoked inotropy by decreasing the $\mathrm{Ca}^{2+}$ contents of $\mathrm{IP}_{3}$-sensitive and RyRsensitive Ca stores to the subthreshold levels for contraction. As a matter of fact, recently there is great and growing interest in cardiac $\mathrm{IP}_{3}$ signaling on intracellular $\mathrm{Ca}^{2+}$ movements in various cardiac cells. Stuyvers et al. demonstrated the existence of $\mathrm{IP}_{3}$ receptors in canine Purkinje fibers by using the immunolabeling study [21]. They also demonstrated that $\mathrm{IP}_{3} \mathrm{Rs}$ and related local $\mathrm{Ca}^{2+}$ release have been observed near the sarcolemmal membrane. These phenomena might constitute the primary event of the sequence leading to large $\mathrm{Ca}^{2+}$ transients and subsequent cell wide $\mathrm{Ca}^{2+}$ waves, which they assume to possibly leads to the positive inotropy in canine Purkinje fibers [21, 24-28]. Taken together various experimental results regarding $\mathrm{Ca}^{2+}$ movements, and the results obtained from the present study, it is highly speculated 
that the activation of $\mathrm{IP}_{3}$ Rs may be involved in $\mathrm{ACh}$-provoked positive inotropy in canine Purkinje fibers. The ACh-induce activation of $\mathrm{IP}_{3} \mathrm{Rs}$ might be related with pathological states such as arrhythmias and heart failure [29].

It is concluded that canine cardiac Purkinje fibers have $M_{3}$ receptors as well as $M_{2}$ receptors. The density of $M_{3}$ receptors are smaller than the density of $M_{2}$ receptors, however, the physiological function was larger than expected from $M_{3}$ receptor density. $M_{1}$ receptors rarely exist, which differs from the other authors' findings. The present study demonstrated that the activation of $\mathrm{M}_{3}$ receptors caused by ACh augments the contractile force possibly by increasing $\mathrm{IP}_{3}$ levels. However, the significance of the functional role of $\mathrm{M}_{3}$ receptors still remains to be elucidated.

\section{Conflict of Interests}

The authors state no conflict of interests.

\section{Acknowledgments}

The authors thank Dr. Shigeru Okuyama, Dr. Takashi Sakagawa at Research Center of Taisho Pharmaceuticals, Dr. Yoko Amagase, Ms. Yuko Yamabe, and Ms. Akiko Takase at Doshisha Women's College for kindly supporting and assisting the present experiments.

\section{References}

[1] E. C. Hulme, N. J. M. Birdsall, and N. J. Buckley, "Muscarinic receptor subtypes," Annual Review of Pharmacology and Toxicology, vol. 30, pp. 633-673, 1990.

[2] Z. Wang, H. Shi, and H. Wang, "Functional M3 muscarinic acetylcholine receptors in mammalian hearts," British Journal of Pharmacology, vol. 142, no. 3, pp. 395-408, 2004.

[3] C. Kohl, W. Schmitz, and H. Scholz, "Positive inotropic effect of carbachol and inositol phosphate levels in mammalian atria after pretreatment with pertussis toxin," Journal of Pharmacology and Experimental Therapeutics, vol. 254, no. 3, pp. 894-899, 1990.

[4] H. Nouchi, S. Kaeriyama, A. Muramatsu et al., "Muscarinic receptor subtypes mediating positive and negative inotropy in the developing chick ventricle," Journal of Pharmacological Sciences, vol. 103, no. 1, pp. 75-82, 2007.

[5] R. F. Gilmour Jr. and D. P. Zipes, "Positive inotropic effect of acetylcholine in canine cardiac Purkinje fibers," The American Journal of Physiology, vol. 249, no. 4, pp. H735-740, 1985.

[6] M. R. Rosen, S. F. Steinberg, and P. Danilo Jr., "Developmental changes in the muscarinic stimulation of canine Purkinje fibers," Journal of Pharmacology and Experimental Therapeutics, vol. 254, no. 1, pp. 356-361, 1990.

[7] G. Malfatto, A. Zaza, E. Vanoli, and P. J. Schwartz, "Muscarinic effects on action potential duration and its rate dependence in canine Purkinje fibers," Pacing and Clinical Electrophysiology, vol. 19, no. 11, pp. 2023-2026, 1996.

[8] J. M. Yang, K. T. Chung, S. N. Yang, and S. Yang, "Muscarinic activation causes biphasic inotropic response and decreases cellular $\mathrm{Na}+$ activity in canine cardiac Purkinje fibers," Journal of Biomedical Science, vol. 6, no. 3, pp. 176-182, 1999.
[9] K. Tsuchida and H. Aihara, "Effects of a K ionophore, lonomycin A, on the action potential in canine cardiac Purkinje fibers," Japanese Journal of Pharmacology, vol. 41, no. 3, pp. 353361,1986

[10] S. Dhein, C. J. Van Koppen, and O. Brodde, "Muscarinic receptors in the mammalian heart," Pharmacological Research, vol. 44, no. 3, pp. 161-182, 2001.

[11] H. Ito, R. T. Tung, T. Sugimoto et al., "On the mechanism of $\mathrm{G}$ protein $\beta \gamma$ subunit activation of the muscarinic $\mathrm{K}+$ channel in guinea pig atrial cell membrane. Comparison with the ATPsensitive K+ channel," Journal of General Physiology, vol. 99, no. 6, pp. 961-983, 1992.

[12] K. Pönicke, I. Heinroth-Hoffmann, and O. Brodde, "Demonstration of functional M3-muscarinic receptors in ventricular cardiomyocytes of adult rats," British Journal of Pharmacology, vol. 138, no. 1, pp. 156-160, 2003.

[13] M. P. Sauviat, "Muscarinic modulation of cardiac activity," Journal de la Societe de biologie, vol. 193, no. 6, pp. 469-480, 1999.

[14] H. Tanaka, K. Nishimaru, R. Makuta et al., "Possible involvement of prostaglandins F2 $\alpha$ and D2 in acetylcholine-induced positive inotropy in isolated mouse left atria," Pharmacology, vol. 67 , no. 3, pp. 157-162, 2003.

[15] H. Tanaka, K. Nishimaru, M. Kobayashi, T. Matsuda, Y. Tanaka, and K. Shigenobu, "Acetylcholine-induced positive inotropy mediated by prostaglandin released from endocardial endothelium in mouse left atrium," Naunyn-Schmiedeberg's Archives of Pharmacology, vol. 363, no. 5, pp. 577-582, 2001.

[16] Y. Hara, A. Ike, R. Tanida, M. Okada, and H. Yamawaki, "Involvement of cyclooxygenase-2 in carbachol-induced positive inotropic response in mouse isolated left atrium," Journal of Pharmacology and Experimental Therapeutics, vol. 331, no. 3, pp. 808-815, 2009.

[17] N. Harada, K. Ochi, N. Yaosaka et al., "Immunohistochemical and functional studies for M3 muscarinic receptors and cyclooxygenase-2 expressed in the mouse atrium," Autonomic and Autacoid Pharmacology, vol. 32, no. 3-4, pp. 41-52, 2012.

[18] S. Ateş and Z. Kaygisiz, "Positive inotropic, negative chronotropic, and coronary vasoconstrictor effects of acetylcholine in isolated rat hearts: role of muscarinic receptors, prostaglandins, protein kinase $\mathrm{C}$, influx of extracellular $\mathrm{Ca} 2+$, intracellular Ca2+ release, and endothelium," Japanese Journal of Physiology, vol. 48, no. 6, pp. 483-491, 1998.

[19] A. W. Trafford, G. C. Sibbring, M. E. Díaz, and D. A. Eisner, "The effects of low concentrations of caffeine on spontaneous Ca release in isolated rat ventricular myocytes," Cell Calcium, vol. 28, no. 4, pp. 269-276, 2000.

[20] P. Pučelík, "Pharmacological blockade of sarcoplasmic reticulum induces a negative lusitropic effect," General Physiology and Biophysics, vol. 26, no. 3, pp. 214-220, 2007.

[21] B. D. Stuyvers, W. Dun, S. Matkovich, V. Sorrentino, P. A. Boyden, and H. E. D. J. Ter Keurs, "Ca2+ sparks and waves in canine Purkinje cells: a triple layered system of Ca2+ activation," Circulation Research, vol. 97, no. 1, pp. 35-43, 2005.

[22] T. J. Hund, A. P. Ziman, W. J. Lederer, and P. J. Mohler, "The cardiac IP3 receptor: uncovering the role of "the other" calciumrelease channel," Journal of Molecular and Cellular Cardiology, vol. 45, no. 2, pp. 159-161, 2008. 
[23] R. A. Haworth, A. B. Goknur, A. V. Biggs, D. Redon, and K. T. Potter, "Ca uptake by heart cells: I. Ca uptake by the sarcoplasmic reticulum of intact heart cells in suspension," Cell Calcium, vol. 23, no. 4, pp. 181-198, 1998.

[24] P. A. Boyden, J. Pu, J. Pinto, and H. E. D. J. ter Keurs, “Ca2+ transients and $\mathrm{Ca} 2+$ waves in purkinje cells: role in action potential initiation," Circulation Research, vol. 86, no. 4, pp. 448-455, 2000.

[25] P. A. Boyden, W. Dun, C. Barbhaiya, and H. E. D. J. ter Keurs, "2APB- and JTV519(K201)-sensitive micro Ca2+ waves in arrhythmogenic Purkinje cells that survive in infarcted canine heart," Heart Rhythm, vol. 1, no. 2, pp. 218-226, 2004.

[26] A. V. Zima and L. A. Blatter, "Inositol-1,4,5-trisphosphatedependent $\mathrm{Ca} 2+$ signalling in cat atrial excitation-contraction coupling and arrhythmias," Journal of Physiology, vol. 555, no. 3, pp. 607-615, 2004.

[27] X. Li, A. V. Zima, F. Sheikh, L. A. Blatter, and J. Chen, "Endothelin-1-induced arrhythmogenic Ca2+ signaling is abolished in atrial myocytes of inositol-1,4,5-trisphosphate(IP3)receptor type 2-deficient mice," Circulation Research, vol. 96, no. 12, pp. 1274-1281, 2005.

[28] M. Hirose, B. Stuyvers, W. Dun, H. ter Keurs, and P. A. Boyden, "Wide long lasting perinuclear $\mathrm{Ca} 2+$ release events generated by an interaction between ryanodine and IP3 receptors in canine Purkinje cells," Journal of Molecular and Cellular Cardiology, vol. 45, no. 2, pp. 176-184, 2008.

[29] A. R. Marks, "Cardiac intracellular calcium release channels: role in heart failure," Circulation Research, vol. 87, no. 1, pp. 8-11, 2000 . 

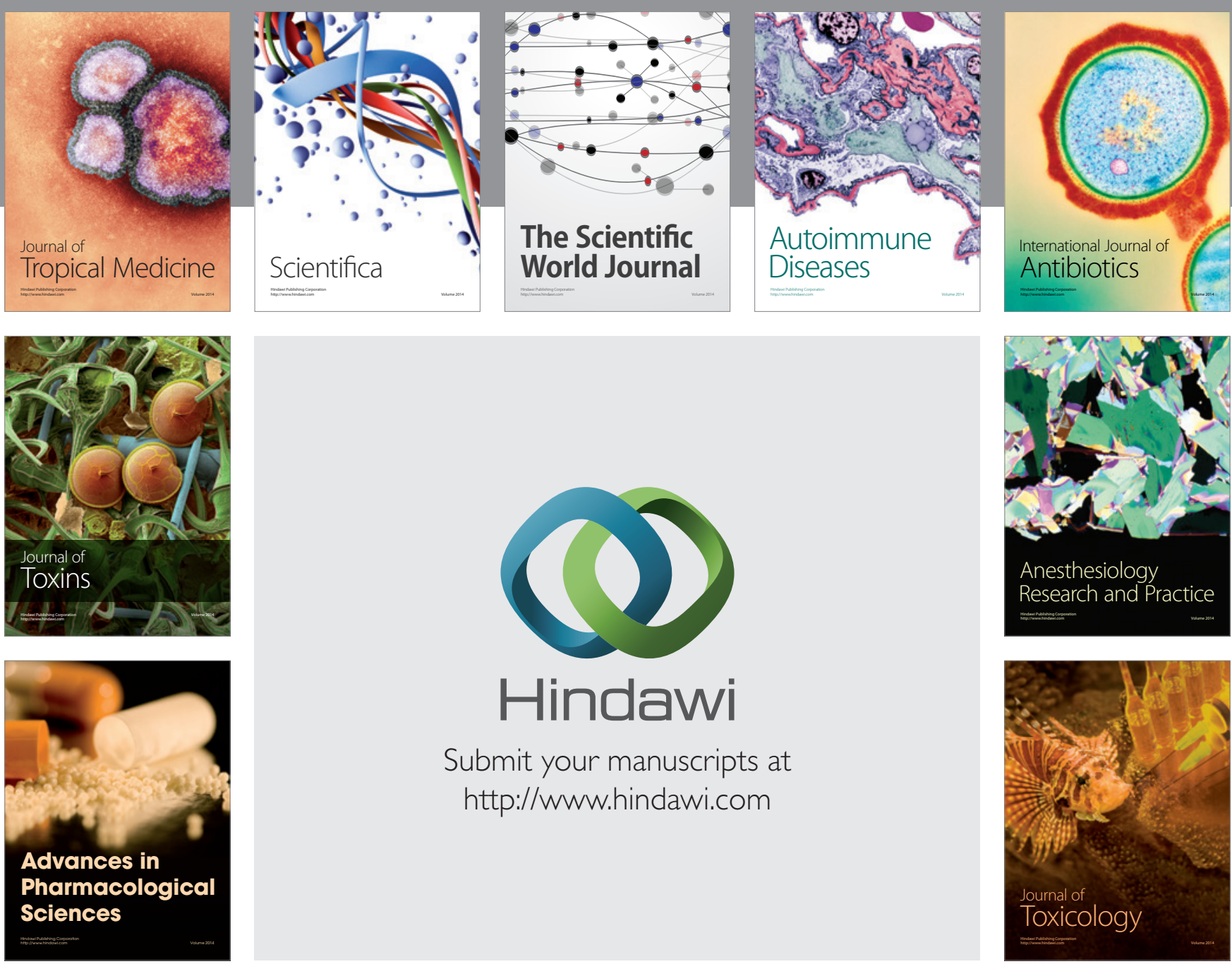

\section{Hindawi}

Submit your manuscripts at

http://www.hindawi.com
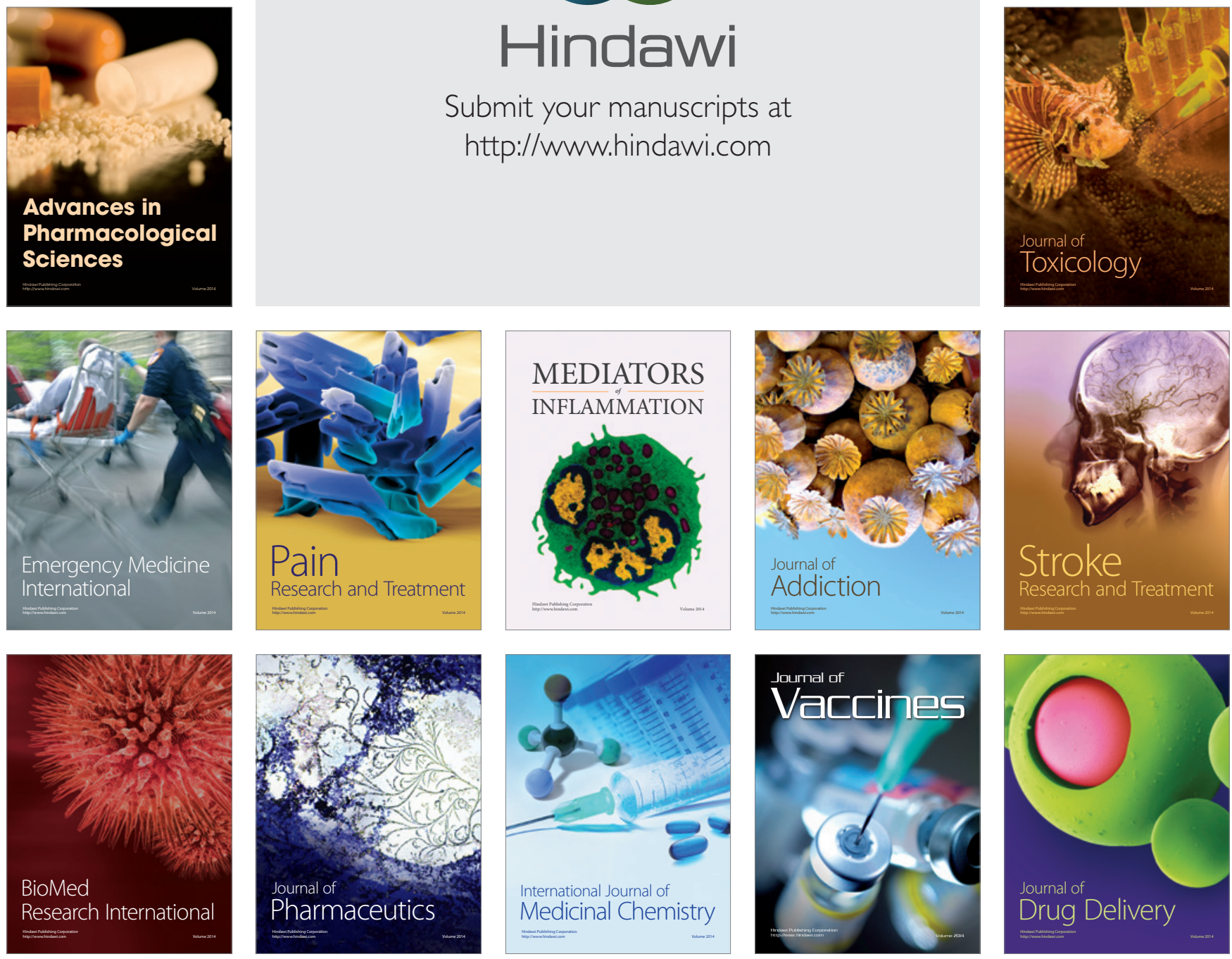